\title{
Os índios Xukuru: entre doces, carnes. Faltando frutas e legumes. Conflitos de terras e fome em Pesqueira na década de 1950
}

The Indians xukuru: between sweets, meats. Missing fruit and vegetables. Land disputes and hunger in fisheries in 1950 decade

Edson Silva*

edson.edsilva@gmail.com

\begin{abstract}
Resumo: Os indígenas Xukuru do Ororubá habitam em sua maioria na Serra do Ororubá (Pesqueira e Poção), no Agreste pernambucano, onde apesar das estiagens periódicas e secas prolongadas, existem áreas úmidas montanhosas e de brejos que foram reconhecidas pelos recursos naturais disponíveis como matas, fontes de água e a riqueza produtiva das terras agrícolas, com o plantio de frutas, legumes e a agricultura de subsistência muito importante para a sobrevivência humana naquela região. As terras habitadas pelos indígenas foram invadidas ao longo dos anos por criadores de gado e o antigo Aldeamento de Cimbres situado na Serra do Ororubá teve a decretada a extinção oficial no último quartel do Século XIX atendendo os interesses dos fazendeiros, restando a alguns indígenas pequenos pedaços de terras e a maioria o trabalho nas fazendas. A partir de uma pesquisa documental e das memórias indígenas, discutimos como as formas de ocupação e uso das terras naquela região com a pecuária e a agroindústria no Século XX, provocaram mudanças nas relações socioambientais e seus impactos sobre a população indígena Xukuru na Década de 1950 como a escassez de alimentos, a fome e a pobreza. Ocorrendo a expulsão dos indígenas de terras onde habitavam, a migração para área urbana da cidade de Pesqueira, o trabalho como operários nas fábricas instaladas na cidade. Situação revertida após muitas mobilizações, conflitos e violências enfrentadas pelos indígenas que retomaram suas terras e conquistaram a demarcação oficial da Terra Indígena Xukuru do Ororubá em 2001.
\end{abstract}

Palavras-chave: indígenas Xukuru do Ororubá, ambiente, mobilizações

Abstract: The Xukuru of Ororubá indigenous live mostly in the Serra do Ororubá (Pesqueira and Poção) in Pernambuco Agreste, where despite the prolonged periodic and dry droughts, there are mountainous and swamps wetlands that were recognized by the available natural resources as forests, sources water and the productive wealth of agricultural land by planting fruits, vegetables and very important subsistence farming for human survival in the region. The lands inhabited by indigenous people were invaded over the years by cattle ranchers and former Cimbres village located in the Serra do Ororubá had decreed the official extinction in the last quarter of the nineteenth century serving the interests of farmers, leaving a few small indigenous pieces land and most of the work on the farms. From documentary research and indigenous memories, we discussed how the forms of occupation and land use in the region with livestock and agro-industry in the twentieth century, caused changes in the socio-environmental relations and their impact on Xukuru indigenous population in the 1950 Decade as food shortages, hunger and poverty. Occurring the expulsion of indigenous land where they lived, migration to urban area of the city of Pesqueira, work as laborers in factories in the city. Situation reversed after many mobilizations, conflict and violence faced by indigenous people who have taken their land and conquered the official demarcation of the Indigenous Land Xukuru the Ororubá in 2001.

Keywords: indigenous Xukuru the Ororubá, environment; mobilizations

\footnotetext{
* Doutor em História Social pela UNICAMP. É professor de História no CENTRO DE EDUCAÇÃO/Col. de Aplicação-UFPE/Campi Recife. Leciona no Programa de Pós-Graduação em História/UFCG (Campina Grande-PB) e no Curso de Licenciatura Intercultural Indígena na UFPE/Campus Caruaru, destinado a formação de professores/as indígenas.
} 


\section{Introdução}

O povo indígena Xukuru do Ororubá habita nos atuais municípios de Pesqueira e Poção. O Censo IBGE/2011 contabilizou a população Xukuru em cerca de 12.000 indivíduos. Com várias famílias indígenas morando em bairros na periferia da cidade de Pesqueira (ALMEIDA, 2000,p. 52), mas a maioria da população indígena habitando em 24 aldeias espalhadas pela Serra do Ororubáe localidades vizinhas na área indígena oficialmente demarcada em 2001.

Os Xukuru do Ororubá habitam no Agreste (Semiárido) pernambucano, uma região intermediária entre o litoral úmido e o Sertão, onde apesar da existências áreas úmidas montanhosas os chamados brejos de altitudes e os de pé-de-serra, ocorrem estiagens periódicas prolongadas e épocas de secas. Parte considerável da população indígena concentra-seem dois brejos, o de São José e no do Ororubá. Nesses espaços de clima ameno, com uma elevada densidade populacional, coexistem atividades agrícolas e a pecuária.

Os brejos possuem solos profundos, matas de serras e cursos d'água permanentes. Favorecendo a policultura tradicional, como a lavoura do feijão, mandioca, café, cana-de-açúcar, a horticultura e a fruticultura, com cultivo de banana, pinha, goiaba, caju, laranja, dentre outras (MELO, 1980, p.176).

Notemos, além disso, que, nesses interflúvios e em outros de menor amplitude aparecem manchas numerosas, que, não chegando a constituir verdadeiros brejos, representam áreas onde se atenuam às condições de semi-aridez, com seus efeitos benéficos nas atividades pastoris. Atenuação dos efeitos da semi-aridez é também a existente nas áreas dos chamados pés de serra, preferidas pela lavoura nos espaços de baixa pluviosidade. (MELO, 1980, p.181).

Durante muito tempo, a produção de frutas e hortaliças dos brejos abasteceu não somente as feiras das cidades próximas, como também até as situadas em bairros do Recife.

$\mathrm{Na}$ pesquisa realizada no Arquivo Público Estadual de Pernambuco, na série de documentos manuscritos daDiretoria de Índios, foram coletadas informações sobre o Aldeamento de Cimbres situado na Serra do Ororubá até a sua decretação oficial de extinção, atendendo interesses dos fazendeiros, no último quartel do Século XIX. (SILVA, 2008). Também no Arquivo Público consultamos exemplares do jornal $A$ voz de Pesqueira que traziam periodicamente artigos assinados e editorias sobre a situação social no município de Pesqueira

Além disso, recorremos a uma literatura específica tratando da dinâmica ambiental do Agreste, particularmente onde estão localizados os atuais municípios de Pesqueira e Poção.As informações documentais e ainda as memorias orais a partir de entrevistas, foram analisadas com o suporte de uma bibliografia histórica geral sobre a presença humana naquela região do Semiárido pernambucano. O que possibilitou traçar um quadro sociohistórico das formas de ocupação e uso das terras naquela região com a pecuária e a agroindústria, a respeito das mudanças nas relações socioambientais e seus impactos sobre a população indígena Xukuru na Década de 1950.

\section{Terras produtivas e com riquezas naturais}

Diversos autores ressaltaram as riquezas naturais e a fertilidade das terras vizinhas e na Serra do Ororubá. No verbete "Cimbres", por exemplo, encontrado no Dicionário Topográfico, Estatístico e Histórico da Província de Pernambuco, publicado em 1863, o autor enfatizou a riqueza natural daquela localidade, quando escreveu: "Não obstante a pobreza da aldeia, o termo é um dos mais ricos e de maior importância no 
Os ÍNDIOS XUKURU: ENTRE DOCES, CARNES. FALTANDO FRUTAS E LEGUMES. CONFLITOS DE TERRAS E FOME EM PESQUEIRA NA DÉCADA DE 1950

Sertão pela riqueza natural e produtiva". (HONORATO, 1976, p.38).

Em seu Diccionario Chorographico, Histórico e Estatístico de Pernambuco, publicado em 1908, Sebastião Vasconcellos Galvão ressaltou a produção agrícola de Cimbres, com milho, feijão, mandioca, algodão, fumo, cana-de-açúcar e batatas. Além de frutas, como ananases, laranjas, cajus, goiabas, bananas e pinha. $\mathrm{O}$ autor frisou, porém, que essa produção advinha da Serra, pois: "Geralmente fraca no município, a agricultura, é futurosa na Serra do Ororubá pela uberdade de que oferece”. (GALVÃO, 1908, p. 181).

Em outro trecho, Galvão afirmou que, além da abundância da criação de gado, cavalos, ovelhas e cabras, existiam animais silvestres na região, como veados, caititus, onças de diversas espécies, raposas, gatos maracajás, tatus, tamanduás, coelhos, mocós, preás, guarás, furões, maritacas, tejus, juntamente com "aves de diversas espécies e portes". Afora o cedro, o autor citou outras árvores nativas e seus usos medicinais:

A aroeira (muito usada no cozimento do entre casca para dores de garganta), o bom nome (com o uso específico das moléstias das vias respiratórias), o jucá ou pau-ferro, o assafraz, guáiaco, cabeça de negro, gitó, parreira brava, japecanga (succedaneo da salsaparrilha), o ingazeiro, jaboticabeira, o imbuzeiro, a catinga de porco (de cujas folhas se faz travesseiros sobre os quais se deitando os doentes de dores de cabeça e tonteiras, dizem cessar o incômodo), o mulungu, o cardeiro (mandacaru), o marmeleiro, o velame o barbatenão, etc. (GALVÃO, 1908, p.181).

O conhecimento do uso dessas plantas medicinais pode evidenciar a sua tradicional utilização pelos indígenas.

O autor também destacou a considerável produção agrícola de Cimbres, onde se colhiam cereais para abastecer as feiras da região. Plantava-se a cana-de -açúcar e existiam os engenhos São Francisco, São José, Pedra D’Água, Minas, Zumbi, São Braz, Conceição, Santa Rita, Santa Catarina, São Marcos, Afetos, Trincheira, Bem-te-vi, Couro d'Anta e Gerimum e "algumas engenhocas de rapadura". Galvão enfatizou a fertilidade das terras do antigo aldeamento, quando afirmou: "O terreno é muito produtivo, principalmente na Serra de Ororubá". Citou ainda artigos produzidos pelos índios, quando escreveu: “A indústria local é a criação, a fabricação de redes e sacos de algodão, de esteiras, chapéus de palha e vassouras, de cachimbos de barro, feitos pelos índios habitantes da serra de Ororubá”. (GALVÃO, 1908, p.182).

\section{As invasões dos fazendeiros}

Historicamente a expansão pastoril no Agreste foi cada vez mais acentuada, restringindo assim as lavouras de subsistência. E os brejos das serras foram sendo usados como refrigério para o gado, em períodos de longas estiagens. O que provocou sérios conflitos socioambientais, com as expulsões dos moradores nativos, os índios pequenos agricultores Xukuru, pelos fazendeiros criadores de gado.

O "Maioral de Cimbres" reclamou em 1853 que as lavouras na "Serra do Urubá" estavam sendo invadidas, "os gados no verão sobem a serra, e estragão as lavoiras, e os criadores recuzão fazer travessõens de serca, para evitar a subida dos gados". Diante das reclamações, o Presidente da Província não só reconheceu os direitos, como acentuou a importância da grande produção dos indígenas para o abastecimento daquela região. Ordenando ao Delegado de Polícia de Cimbres que obrigasse os criadores a fazer as cercas, ou retirar o gado dos lugares cultiváveis "terreno que sempre foi destinado a plantaçõens, e que por sua extraor- 
dinária produção pode fazer a abundância de viveres naquele Certão."1

Um abaixo-assinado de "índios da extinta Aldeia de Cimbres" (atual Pesqueira), com 192 assinaturas foi enviado, em 1885, ao Presidente da Província de Pernambuco. No longo texto que antecede os nomes dos signatários, os indígenas apelavam para o senso de justiça da autoridade provincial, pedindo providências para "fazer cessar as perseguições de que são vítimas". Informando os índios que as terras públicas, onde se encontravam, estavam sendo invadidas por "verdadeiros intrusos".

Os indígenas que se ocupavam "exclusivamente do trabalho da agricultura" para se manter, denunciavam as invasões das terras, por fazendeiros. A exemplo de um fazendeiro que fugindo da seca na Paraíba, invadiu uma das áreas mais férteis na Serra do Ororubá, com seu gado destruindo as roças dos indígenas que, por serem pobres, estavam sendo explorados e não eram ouvidos em suas queixas, pelas autoridades policiais,

Indivíduos sem título algum, entre eles, José Alexandre Correa de Mello, que vindo dos lados do cariri pela seca, apossou-se de um dos melhores sítios do extinto aldeamento, e ali tem fundado, por assim dizer, uma fazenda de gado, que cotidianamentedestrói as lavouras dos suplicantes, que recorrendo à proteção legal, recorrendo às autoridade policiais não são atendidos, porque são desvalidos, são índios miseráveis, e como tais sujeitos a trabalharem como escravos para os ricos e poderosos! $!^{2}$

Os fazendeiros perseguiam os queixosos, que eram presos e processados. Como aconteceu com Manoel Felix Santiago, o índio que encabeçava o abaixo-assinado: "por não ter cedido do seu direito" foi preso, mas absolvido.

Os indígenas afirmavam que, com a extinção do aldeamento, o Governo Imperial determinara "a demarcação dos terrenos que lhe eram pertencentes". Mas, embora tendo sido publicados os editais, pela Tesouraria da Fazenda, para propostas de agrimensores executores da medição, até aquela data a medida não fora realizada, sendo as terras invadidas por "intrusos", fazendeiros criadores de gado, destruidores das lavouras dos índios, "para que assim os suplicantes perseguidos abandonem as suas antigas e legítimas posses!"

No citado documento, lembravam ainda os indígenas que Manoel Felix Santiago, superando "sérias dificuldades", fora "pessoalmente" procurar o Imperador no Rio de Janeiro, tendo sido orientado para se dirigir ao Ministro da Fazenda e este recomendara ao Presidente da Província tomar as providências necessárias para retirar os "intrusos" que invadiram as terras do antigo aldeamento. Afirmavam os signatários que cabia à autoridade provincial determinar ao Juiz Comissário da Comarca cumprir a lei.

A pesquisa documental demonstrou que a extinção oficial, em 1879, do antigo Aldeamento de Cimbres, consolidou o domínio dos fazendeiros, de longa data invasores nas terras da Serra do Ororubá. Para uma ou outra família indígena restou a propriedade de pequenos pedaços de terras, insuficientes para a sobrevivência.

Em suas memórias orais os Xukuru do Ororubá se refeririam a essa situação. A exemplo do relatado pela índia Laurinda Barbosa dos Santos, conhecida por "D. Santa", moradora na atual Aldeia Caípe. Seus pais

\footnotetext{
${ }^{1}$ Ofício do Diretor Geral dos Índios, em 07/07/1853, ao Presidente da Província de Pernambuco. Arquivo Público Estadual Jordão Emereciano/APEJE, Códice DII-10, folha 25

2 Abaixo-assinado de índios da extinta Aldeia de Cimbres, em Pesqueira 25 de fevereiro de 1885, para o Presidente da Província. APEJE, Cód. Petições, fls. $18-23 \mathrm{v}$.
} 
nasceram na "Serra", o pai em Pendurado e a mãe em Caípe, local onde, depois de casados, moraram e viveram. "D. Santa" disse ainda que trabalhou na roça desde oito anos. Questionada se os moradores e parentes vizinhos tinham terras para plantar, ela afirmou: "Tinham bem pouquinha! Porque não podia comprar. Naquele tempo tudo era comprado e ninguém podia, os pais de nós não podia que era tudo pobrezinhos. Só vivia trabalhando no alugado que era para dar de comer aos filhos. Era terras dos fazendeiros" (SANTOS, 2005).

Outros entrevistados, em diferentes localidades na Serra do Ororubá, também afirmaram a falta de terras para trabalho e sobrevivência. Como "Seu" Cassiano, nascido e vivendo na Aldeia Cana Brava, quando afirmou que o seu pai só "Tinha 4 quadros de terras. Não dava para viver. Não dava porque ele trabalhava alugado. Ele só no alugado coitado, se entertia naquilo". Isso porque, segundo ele: "Aqui todo mundo era dono de pequenos pedaços de terras, cercado de fazendeiros, Zé Zacarias, Arlindo Sabino, Bernardo, Zé Marques, Antônio de Zumba. Tinha gado e sítio. No Sítio do Meio era terra de gado, por todo o canto era gado!" (SOUZA, 2005).

Ainda em Cana Brava, outro entrevistado, cujos pais nasceram e viveram naquela localidade, falou da falta e das dificuldades do acesso à terra para o trabalho, devido à exploração e pressão dos fazendeiros, como afirmou "Seu" Juvêncio:

A dificuldade era grande. Desde o meu tempo, eu cai no trabalho da agricultura com dez anos de idade! Porque o ramo dos meus pais, dos meus avós, tudo era trabalhar na agricultura. Mas não existia terra para trabalhar! Não existia terra para trabalho. Nós trabalhava arrendado com fazendeiro. Você botava meio hectare de terra ou um hectare. Fazia a broca, fazia a terra, plantava, quando a lavoura, quando nós plantava que nascia, o fazendeiro já danavacapim dentro! Nós trabalhava arrendado! Porque ali não desfrutava nada! Quando tava começando a desfrutar, ele já botava o gado dentro! Pronto, acabava com tudo, nós ficava sem nada. (SILVA, 2005).

Em Brejinho, a situação era semelhante. Ao ser perguntado se seus pais tinham terras para trabalho, "Seu" Malaquias afirmou que trabalhavam somente em terras nas mãos dos fazendeiros:

Terra tinha na fazenda. Própria não. Tinha a moradia. Plantavam um ano ali num lugar cercado, plantava milho, feijão, plantava o que quisesse esse ano, $e$ outro ano, mudava lá outro cercado. Agora nesse ano trabalhava aqui plantava capim e aqui não trabalhava mais, ai mudava para outro, botava os roçados, botava o capim, mudava para outro. (RAMOS, 2005).

A opção para os índios sem terras era o chamado trabalho alugado. E também aumentava a pressão dos fazendeiros sobre aqueles que possuíam pequenos pedaços de terras, arrendando-as, comprando-as, tomando -as a força. O que provocou a dispersão de famílias indígenas, como relatou "Seu” Gercino:

E pagava a renda com a planta do capim ou da palma. Era. E o indio tinha que fazer aquilo mesmo. E eles aqueles, os indios que tinham um pedacinho de terra, ai foram apertando, os fazendeiros foram apertando, foram apertando e eles tudo de boca aberta, nem davam o roçado, nem arrendava e nem nada. Eu compro seu pedacinho de terra e eles besta comprava, vendia ou vendia. Vou sair daqui que doutor fulano vai tomar conta disso aqui e depois pode dele não querer pagar e nós perde, vendiam. Vendiam e iam pra rua e outros ia s'imbora pelo mundo, por ai afora, vivia por esses cantos. (SILVA, 2005)

Em outras localidades, algumas famílias herdaram dos seus antepassados pequenos pedaços de terra, como afirmou "Seu" Milton: "Meu pai tinha um pouquinho de terra, pouquinho. É três hectares e meio, a terra do meu pai. Foi herança da minha mãe. Ainda hoje eu tenho essa terra, ainda eu possuo essa terra. Têm 
umas terras pequenininhas, todos eles moram numa terra bem pequenininha mesmo". (CORDEIRO, 2005).

Como também relatou "Seu” Dedé, nascido em Sanharó, cidade próxima a Pesqueira, porque seus pais tinham migrado em razão da falta de terras para trabalho; voltou à Serra do Ororubá para morar em um pedaço de terra que fora da avó da sua esposa. Falando ainda sobre as pressões dos fazendeiros vizinhos para tomar-lhe as terras:

A terra que a gente tinha aqui era dez conta de terra. Era quinze braça por oitenta de altura. Quer dizer que nos papéis da escritura tinha dez conta de terra. A gente não tinha espaço pra nada, porque de um lado o fazendeiro, do outro o fazendeiro. A gente tava como um pão que a gente pega ele e abre no meio e coloca um pedaço de doce e faz sanduiche, a gente tava ali naquela tirinha imprensado e ele imprensando mais pra gente correr, conseguir correr dali e ele tomar conta. (PAZ, 2004).

O Pajé Xukuru, "Seu” Zequinha, recordou que a falta de terras obrigava a trabalhar para os fazendeiros. Ele próprio trabalhou nessas condições. Quando era de seu interesse, os fazendeiros cediam terras para trabalho em regime de pagamento com a maior parte da produção, colhida às pressas. Uma pressão crescente até a expulsão dos pequenos proprietários:

Quem ficou com uns pedacinhos, ainda trabalhava naqueles pedacinhos deles $e$ quem não tinha, tinha que trabalhar a roubo. $O$ pessoal, o fazendeiro abria campina, andava aquele roçado. Eu mesmo trabalhei muito nas propriedades do povo, dos fazendeiros. Eu pagava um saco de milho por quadra, pagava. $O$ pagamento era um saco de milho e a prestação ficava. Fechava pra estação e a fava que a gente ficava, ele não deixava nem amadurecer direito, o camarada apanhava verde mesmo, ai que nós vivia assim, mas teve uma época, que não teve nada. Os fazendeiros tomaram conta. (BISPO, 2004)

O entrevistado ressaltou que os despossuídos de terras eram os mais oprimidos pelos fazendeiros, que soltavam o gado no plantio, antes do término da colheita:

\begin{abstract}
Esses é que sofriam demais! Onde trabalhar? Só era do fazendeiro fazer deles o que queria. Dava um pedacinho de terra deste tamanho assim para trabalhar, não deixava a fava criar nem caroço, nem secar, apanhava verde, o milho quebrava verde, ainda o leite correndo pro gado não comer. "Vou botar o gado!". Muitos já quebrava com o gado dentro! O fazendeiro botava, cada vez mais apertava a dobradiça. (BISPO, 2004).
\end{abstract}

As lembranças das relações de trabalho na condição de moradores nas terras por anos em mãos dos fazendeiros também foram relatadas ainda por "Seu” Juvêncio:

\begin{abstract}
Quem não tinha terra, morava de favor, morava com os brancos, eles botava lá. Eles botava eles para morar, dava uma moradia a eles, botava eles para morar e prá trabalhar eles direto! Trabalhar eles direto! Nunca teve futuro. Eu mesmo trabalhei muito para outros. Trabalhei muito alugado. Eu trabalhei de 1952 para cá, eu morei com o fazendeiro aqui Antônio Zumba, era o homem mais rico dessa região! O nome dele era Antônio Zumba. Agora que ele era muito bom. Ele era muito bom. $O$ nome dele era Antônio Zumba. Só com ele eu trabalhei 32 anos. (SILVA, 2005).
\end{abstract}

Um número considerável de indígenas moradores na Serra do Ororubá, foi forçado a abandonar os antigos locais que habitavam e migrar para a periferia da cidade de Pesqueira. Muitos passaram à condição de mão-de-obra para as fábricas, como fornecedores de matéria prima, ou como operários.

\section{Mudanças socioambientais: a agroindús- tria}

O estudo das mudanças ambientais é uma abordagem recente na área da História. A pesquisa em História Ambiental, de toda maneira, até pelo próprio fato de ser "ambiental", não é realizado com a abstração das teorias puras, mas sim nas contradições de lugares e 
experiências vividas. Na maioria das vezes, ocorre por meio de recortes geográficos e biofísicos concretos: uma região florestal, uma bacia hidrográfica, uma cidade, uma zona agrícola etc. (DRUMMOND, 1991, p.181). É, portanto, a partir dessa perspectiva que discutiremos as mudanças socioambientais em Pesqueira e suas consequências para os índios Xukuru entre as décadas de 1940/1950.

Uma crônica publicada pelo Pe. Olímpio Torres com o título "Serra do Ororubá" publicada em 1953 em um semanário de Pesqueira comparava a cidade ao município de Triunfo, "um oásis de fartura no Sertão". Também situado em uma região montanhosa, Triunfo, bem menor que Pesqueira, era um município rico, isso porque cada família tinha um pedaço de terra, com centenas de engenhos, casas de farinha e considerável produção agrícola, significando fartura. Em Pesqueira, existia uma lógica inversa, a da era do boi, que provocaria, em breve, a falta de alimentos, pois os agricultores são empurrados para a ribeira estéril, se não quisessem ser operários na cidade. Diante dessa situação afirmava o religioso:"E o município, que outrora se bastava a si mesmo e ainda abastecia outros mercados, hoje é quase faminto e dentro pouco tempo estará importando até maxixe". (TORRES, 1953a, p.1)

A "ribeira" citada situava-se ao longo das margens do Rio Ipojuca que, em épocas de secas, tornavase um filete de água, sem garantia para a sobrevivência dos moradores próximos. Na semana seguinte, foi publicado mais um artigo invocando a necessidade da solidariedade humana, frente a uma situação de crescente miséria para muitos e riqueza de poucos, escreveu o padre: "O problema da Serra do Ororubá entregue aos bois, para riqueza de meia dúzia, enquanto os seus antigos agricultores definham numa miséria sempre crescente - é uma pedra de toque por onde se pode auferir do bom senso e do espírito de humanidade daqueles que falam do assunto.” (TORRES, 1953b, p. 1)

Com a lucrativa expansão da pecuária, mesmo as fazendas de algodão e os cafezais erradicaram seus plantios:" Para o proprietário, a partir de quando se tornou desinteressante ceder terras em parceria ou em arrendamento para pequenas lavouras, o que passou a interessar foi, sobretudo, o retorno das glebas cedidas cobertas com restos de culturas, para seus animais, ou com pastos plantados". (TORRES, 1953b, p.1). Restava ao pequeno agricultor indígena na Serra do Ororubá pequenas parcelas de terras, os chamados "sítios", insuficientes para a sua subsistência e da sua família.

O estudo de um geógrafo em 1956, ainda que não faça nenhuma referência aos índios habitantes na Serra do Ororubá, descrevia a localidade como uma região de solo arenoso e pedras com clima semiárido e também semiúmido, onde, durante boa parte do ano, predominava a seca. O gado dividia o espaço com lavouras e plantações de tomate:

O pardo triste da vegetação então despida de folhas e o aspecto agoniado das cetáceas põem em destaque o viço lustroso das cercas vivas dos aveloses que cumprem, entre outras utilidades, a função de separar as áreas do criatório extensivo, em campo aberto, dos tratos de terras culturáveis, enquanto que apenas aqui e ali, em locais aparentemente escolhidos a dedo, algumas raras unidades arbóreas, também sempre verdes, espalmam suas frondes proporcionando o bem - estar de uma sombra. Paisagem esta ainda mais desoladora posta em comparação com a outra, a da época das chuvas miúdas, quando as caatingas reverdecem e florescem em todo seu esplendor, permitindo a colheita de frutos silvestres, a engorda do gado e o trabalho agrícola nos roçados e nas plantações de tomate (SETTE, 1956, p. 8).

Os citados roçados possivelmente eram os sítios, pequenas glebas de terras espremidas entre as áreas de criação das fazendas, que permaneciam nas mãos de umas poucas famílias indígenas. $\mathrm{O}$ mesmo es- 
tudo apontava o desmatamento recente das matas existentes nos brejos úmidos característicos da Serra. Restavam insignificantes "retalhos de matas testemunhos", pois as matas de outrora continuavam a serem substituídas por cafezais, plantações de goiabeiras, bananeiras e outras frutas. Produção essa destinada às fábricas de doces em Pesqueira. As matas eram derrubadas também para abastecer de lenha as locomotivas do trem que ligava Pesqueira ao Recife, "as fornalhas das fábricas de doces, os fornos de padaria e fogões domésticos". Ocorria, portanto, a destruição do patrimônio natural da Serra, para atender as exigências da lógica econômica em vigor.

A partir dessa lógica, a Serra fora toda ocupada. Nas localidades mais úmidas predominava a criação do gado de corte e o destinado à produção de leite. Nos sopés da Serra, mais próximos da cidade, constatava-se a plantation do tomate destinado à indústria, "enxotando cada vez mais para longe os roçados de subsistência ou mesmo reduzindo as áreas de criação". (SETTE, 1956, p.12)

O combustível utilizado pelas fábricas eram madeiras trazidas da Serra. A lenha utilizada na indústria provocava: "A destruição do revestimento vegetal primitivo. As matas do Ororubá e as caatingas altas dentro de uma área de enorme raio acham-se praticamente desaparecidas". O desmatamento acelerado, além de influir nas condições do solo na região, prejudicava desde os pequenos agricultores aos fazendeiros, comprometia até a própria indústria:

Também a devastação das matas para exploração da lenha, como já ficou assinalado, não só modifica a paisagem fisica, mas igualmente altera e dificulta as possibilidades agropecuárias dos fazendeiros e pequenos plantadores, devido ao aceleramento dos processos de erosão dos solos no alto da Serra e ao rápido escoamento e evaporação das águas no pediplano. (SETTE, 1956, p. 14)

Para o citadogeógrafo, a criação de gado era também a grande responsável pela degradação na Serra, pois existia "o costume, aliás, já antigo de alguns criadores em soltar os seus gados dentro das mangas de refrigérios nos brejos úmidos da Ororubá”. (SETTE, 1956, p. 84) Esses espaços citados pelo estudioso eram locais de clima ameno e irrigados por riachos e fontes de água, onde se concentravam as roças dos pequenos agricultores, os índios cujas terras eram invadidas pelo gado, principalmente nas épocas de longas estiagens.

Em suas memórias, os índios Xukuru do Ororubá falaram dos plantios existentes na Serra do Ororubá destinados à indústria de doces, e ainda da época em que trabalharam nas fábricas em Pesqueira. O Pajé Xukuru falou que os plantios de goiaba se espalhavam por toda a Serra, em terras ocupadas por outros fazendeiros. A colheita era grande, nas safras da fruta:

Era muita goiaba! Tinha muita goiaba! Saía dez, doze caminhões de goiabas daqui de cima dessa Serra. Da terra da gente, mas nas mãos dos fazendeiros: São José, Cana Brava ela toda, ali em Caetano, por ali afora, por essa região quase toda. Em Vila de Cimbres, também tinha muita goiaba. Quando era a goiaba, era goiaba em todo o canto. Porque tinha muita goiabeira. (BISPO, 2004)

As terras férteis da Serra do Ororubá foram ocupadas pelas fazendas de gado ou pelo plantio de frutas e tomates destinados à indústria doceira instaladas no município. Com suas terras invadidas, uma das poucas alternativas que restava então aos Xukuru era o trabalho como operários nas fábricas de doces em Pesqueira.

Com a estrada de ferro partindo de Caruaru e que chegou até o município em 1907, a cidade consolidava-se como entreposto comercial e ocorreu também um grande impulso no crescimento urbano. $\mathrm{O}$ transporte rápido e barato possibilitou à fábrica de doces "Peixe", fundada pela família Brito, em 1902, ampliar sua produção para novos mercados. Possibilitando com isso a adoção de inovações tecnológicas, como a substituição dos tachos aquecidos à lenha pelos a vapor e o 
surgimento de uma outra indústria doceira, a fábrica "Rosa", de propriedade da família Didier. (SETTE, 1956, p. 92).

As frutas destinadas à indústria de doces provinham principalmente das terras férteis da Serra do Ororubá. Multiplicou-se por toda a Serra os plantios de goiabas e bananas. As fazendas de gado estimularam o surgimento de fábricas de laticínios. Por volta de 1914, foi iniciado o beneficiamento do tomate, pela fábrica "Peixe", necessitando de áreas para o plantio do produto. Ampliava-se o parque industrial, com a instalação de mais unidades da "Peixe" e novas fábricas, como a Tigre, Paulo de Brito, Peixinho, Recreio. (SETTE, 1956, p.93)

Era grande também a produção de tomate colhida nas margens do Rio Ipojuca e povoados adjacentes, inicialmente sem o uso de agrotóxicos, pois, só mais tarde apareceram as pragas:

Plantava aqui nessa ribeira: Pão de Açúcar e nessa região para sair para Arcoverde, Alagoinha, Papagaio, Mutuca, em todo o canto eles plantavam. Era muito tomate também! Não existia essa doença de tomate. Não existia não. Plantavam a granel. Ela dava a torto e a direito. Não usava veneno. Não sei que praga foi que deu...dava a granel. (SETTE, 1956, p. 94)

Grande parte dos trabalhadores da fábrica Peixe era composta de índios vindos da Serra do Ororubá. O próprio Pajé Xukuru trabalhou nas fábricas, inclusive na "Peixe". Durante a colheita das grandes safras, nas fábricas em Pesqueira muitos trabalhavam, mas sem vínculo empregatício. Trabalho duro e considerado sujo, no período noturno, para fugir à fiscalização trabalhista, como disse o Pajé Xukuru:

Muitos sem carteira assinada. A noite tinha uma história de uma "virada", chamava-se "a virada", os "porcos" porque trabalhava no leite, de noite, na tomate. Serviço sujo, ai chamavam assim. Quando a safra era grande, quando a fábrica não vencia para trabalhar só o dia. Ai tinha que trabalhar à noite porque era muita polpa. (BISPO, 2004).

As "viradas", como se chamava o trabalho noturno era um serviço pesado, sem os devidos direitos trabalhistas, como recordou Seu Juvêncio, outro entrevistado: “Trabalhei nas viradas. As 'viradas' parece que era três mil reis ou era quatro mil reis. Era de noite. A gente ia trabalhar de noite. Serviço pesado, carregar caixas nas costas, descarregar caminhão, todo molhado.

Sem registro. Tempo difícil”. (SILVA, 2005)

$\mathrm{O}$ crescimento industrial favoreceu a concentração de renda expressa no casario de famílias abastadas. Como também ocorria o surgimento de aglomerações na periferia urbana, formadas, em sua maioria, pelas habitações do operariado. Dentre estes, muitos eram índios da Serra do Ororubá, que se concentravam no Bairro "Mandioca", assim descrito pelo anteriormente citado geógrafo,

Acomodando-se a um desvão oferecido pela escarpa inferior da Ororubá, o bairro Mandioca, tendo a sua localização determinada pela proximidade da água e do centro urbano, atravessa com suas ruas mal cuidadas e suas casas de gente muito pobre o vale do Baixa Grande, começa a subir, do outro lado, a contraencosta e um de seus arruados de casebres, quase trepados uns sobre outros. (SETTE, 1956, p.76-77)

Eram moradias muito pobres comparadas pelo citado pesquisador às "favelas" das grandes cidades. Atualmente, o local é chamado "Bairro Xucurus", e reúne a grande maioria das famílias indígenas na área urbana de Pesqueira. Em conversas informais, moradores locais mais velhos afirmam que muitas dessas famílias foram expulsas de seus sítios na Serra, por fazendeiros invasores. 
A falta de alimentos: pobreza e miséria para os índios

A apropriação das terras pelos fazendeiros criadores de gado com o cultivo de pastagens a partir de meados do Século XIX, e posteriormente a consolidação da agroindústria de doces e conservas baseada na lavoura do tomate e o plantio de frutas, estabeleceu um novo ciclo de relações sociais naquela região. $\mathrm{O}$ discurso que na década de 1950 exaltava o progresso e a riqueza de Pesqueira a chamada "cidade das chaminés" escondia outra situação: a falta da produção de alimentos, a favelização do município, a fome e a miséria.

As difíceis condições de vida na Serra do Ororubá eram semelhantes para a população pobre na cidade. Pois muitos índios moradores na Serra, enxotados pelos fazendeiros, migrarem para a área urbana de Pesqueira, agravando a situação social. No semanário local, um colunista bradava providências policiais contra a prática nociva da mendicância, pois pedintes de esmolas perturbavam as portas das casas, desde bem cedo até próximo à hora do recolhimento das famílias. Acusava o colunista que, mesmo com as chuvas, que possibilitariam trabalho para todos, os mendigos profissionais atuavam. Eram muitas crianças, algumas bem pequenas, incentivadas pelos seus pais a esmolarem. Para o cronista, sobre "uma medida acertada" como a solução enérgica seria a prisão daquela gente vadia. Tratava -se de uma visão, no mínimo, equivocada, pois os depoimentos revelaram que não existia disponibilidade de terras para o trabalho, uma vez que estas estavam sob o domínio dos fazendeiros.

Outro olhar sobre o que se passava é encontrado em outro artigo do Pe. Olímpio Torres com o título "A feira" publicado dias depois, no mesmo jornal. Discutia o autor a diminuição da produção de alimentos e o elevado custo de vida que se refletiam na feira de Pesqueira. Os preços eram temas de conversas públicas causan- do revolta e questionamentos sobre os responsáveis por aquela situação. Os agricultores eram acusados pelo alto preço da farinha.

Porém, escrevia o cronista que os agricultores "Não plantaram mandioca dentro das plantações de tomate e por isso a farinha subiu. Eles não fizeram nenhuma roça de milho e feijão no lombo de cada boi que pasta na Serra - e por isso o povo passa fome". (TORRES, 1953c, p.1) A mendicância, que tanto incomodava os moradores urbanos em Pesqueira, resultava da falta de fornecimento de gêneros alimentícios, outrora produzidos pelos agricultores índios na Serra do Ororubá, invadida pelas fazendas de gado e pelos plantios de tomate, que resultou na expulsão de seus moradores, produzindo mendigos para nas ruas da cidade.

Diante da situação de miséria generalizada o poder municipal determinou o recolhimento, à Delegacia de Pesqueira, e posterior devolução aos pais, de "vários meninos de 5 a 12 anos de idade, que andavam a perambular pelas ruas, mendigando de porta em porta”. (TORRES, 1953d, p.1) A iniciativa, considerada por alguns como uma medida acertada, cumprira ordens do juiz municipal que determinara enérgicas advertências aos pais, embora como registra o jornal, ocorreram protestos e algumas reações sociais, por se tratarem de crianças menores mantidas na delegacia.

Vários artigos publicados nos jornais registram um debate em Pesqueira sobre as fazendas de gado que invadiram a Serra do Ororubá, expulsando seus antigos moradores, os índios agricultores que abasteciam com sua produção o município, ocasionando assim a falta de alimentos, a elevação do custo de vida e, sobretudo, a mendicância nas ruas da cidade, era uma discussão sobre a nova ordem socioeconômica, na qual o gado ocupava o lugar central. Não se tratava simplesmente de uma discussão do confronto lavoura versus pecuária, como afirmavam alguns. Era um debate sobre uma situ- 
ação bem mais grave, que envolvia os motivos dos conflitos e a expropriação secular dos índios de suas terras.

\section{Considerações finais: um novo tempo}

Em fins de 1950 o jornal A gazeta de Pesqueira publicava um artigo não assinado com o título "A carência de frutas e legumes", (CHACON, 1950, p.1) onde o autor iniciava afirmando que cem anos passados os "caboclos da Serra Ororubá" enviavam petição as autoridades reclamando que as invasões provocadas pelo gado impediam o cultivo das lavouras de subsistência. O cronista situava com o passar dos anos a expansão pastoril na Serra do Ororubá e adjacências onde tudo foi transformado em pastagens para o gado! E na medida em que isso acontecia desapareciam desde as roças de mandioca aos pés de fruteiras e legumes. Os alimentos passaram a ser comprados de cidades na região e os preços subiram vertiginosamente.

Os dados sobre óbitos na década de 1940/1950 disponíveis nos arquivos da Prefeitura Municipal de Pesqueira evidenciaram uma elevada taxa de mortalidade infantil. Muitas crianças de apenas meses pereciam, ou ainda nos dois primeiros anos de vida, nos "sítios" Cana Brava, São José, Santana, São Braz, Tionante e Lagoa, todos localizados na Serra do Ororubá. Na documentação estavam registradas também mortes de pessoas adultas, em sua maioria com idade avançada, que, assim como as crianças, com sobrenomes de conhecidas famílias que continuaram habitando nessas localidades.

Após ouvir o comentário sobre os dados dos óbitos infantis, "Dona Zenilda" lembrou que as mortes ocorriam por desnutrição, em razão da falta de terras e melhores condições de vida:

A morte de crianças era por desnutrição. Os pais não tinham leite para as crianças. A desnutrição era grande. Os pais não tinham dinheiro para comprar leite ao fazendeiro. Muitas crianças morriam por desnutrição. Nos meses de maio e junho por causa da frieza. Muitas nasciam já desnutridas por falta de alimentação das mães grávidas. (ARAÚJO, 2005).

A entrevistada recordou também as difíceis condições de saúde e que as próprias famílias providenciavam os sepultamentos das crianças. Os caixões eram feitos com tábuas disponíveis nas "bodegas" locais. Na atual Aldeia Cana Brava, existia um especialista em fazer caixões para as crianças que morriam:

Os pais faziam os caixãozinhos de tábuas de caixas de sabão que vendiam nas vendas. "Seu" Tibúrcio em Cana Brava era o fazedor de caixões dos "anjinhos!". Não havia estradas dos sítios para Pesqueira, o acesso a médicos era difícil. As parteiras faziam o que podiam. Muitas crianças nasciam e morriam em seguida. (ARAÚJO, 2005).

Em suas memórias, outros entrevistados falaram em períodos difíceis. Com as precárias condições de vida e devido à fome, ocorria à mortandade de crianças, como lembrou "Dona Lica":

Morria muitas crianças. Filhos do meu marido (do $1^{\circ}$ casamento dele) morreram sete. Não tinha assistência médica. Morria muita criança de fome. Morria as crianças porque dava farinha para as crianças comer, com papa d'água. A mãe dele (o marido) contava que ele foi criado com batata. Nascia muitos gêmeos. Criava com pano, minha sogra, a mãe dele, contou que criou dois com a saia dela. Não tinha o que comer, ela ia arrancar batata e fazia o mingau. Ela disse que ia nas matas, a mãe de Brivaldo, muitas vezes ia na mata, tirava muncunã (raiz tóxica)lavava em nove águas, se errasse morria. (ARAÚJO, 2005).

Outro entrevistado, Seu Juvêncio, nascido e sempre morador em Cana Brava, lembrou também da falta de assistência médica e da fome, que provocava os óbitos de crianças:

Aqui passava muita fome, nessas épocas! Que não tinha ajuda, não tinha ajuda de nada! Não tinha ajuda de nada, de jeito nenhum! Não tinha terra de jeito ne- 
nhum, não tinha nada. Muitas crianças morriam na minha época. Hoje melhorou muito. Morria de doenças. Hoje melhorou muito! Porque antigamente aqui não tinha médico. Não existia médico. Morria de fome também. Morria desnutrido, de fome, porque não tinha de quê. (SILVA, 2005).

A situação de penúria em razão das invasões das terras indígenas na Serra do Ororubá pelos fazendeiros perdurou por muitos anos. Índios arrendavam suas próprias terras, em mãos dos fazendeiros, para trabalharem. A grande maioria, porém, recebiam míseros pagamentos como trabalhadores para os invasores. Tal situação mudou a partir dos anos 1980, quando liderados pelo Cacique "Xicão" (Francisco de Assis Araújo), os Xukuru estimulados pela participação nas mobilizações da Assembleia Nacional Constituinte que reconheceu e fixou os direitos indígenas na Constituição aprovada em 1988, iniciaram a retomada dos seus territórios. Para impedir a organização e mobilização indígena os fazendeiros planejaram o brutal assassinato do Cacique "Xicão" ocorrido em 1998. A despeito dos assassinatos posteriores de outras lideranças como "XicoQuelé", das perseguições e ameaças, os Xukuru do Ororubá tiveram suas terras homologadas pelo Governo Federal, em 2001 .

Por meio da pesquisa documental e das memórias orais indígenas, percebemos elos de uma história coletiva, de um pertencimento, em um conjunto de situações e experiências históricas socioambientais que conferem uma identidade indígena Xukuru, baseada em um espaço ancestral comum, a Serra do Ororubá. Daí ser possível afirmar a existência de uma memória coletiva. (SILVA, 2008)
Atualmente Cerca de $97 \%$ do território demarcado está nas mãos dos Xukuru, restando ainda ao poder público, indenizar, segundo a lei, as benfeitorias de pequenos posseiros invasores das terras indígenas. Apesar da degradação ambiental com o mau uso dos recursos naturais pelos invasores ao longo de anos, a demarcação foi a concretização do sonho tão esperado, que vem possibilitando a fartura, o vicejar da vida, a dignidade. Produtos agrícolas orgânicos, trazidos por índios de algumas aldeias na Serra do Ororubá e que são vendidos em uma feira semanal no centro de Pesqueira, são representativos de uma nova etapa na história do povo Xukuru.

O objetivo desse texto foi evidenciar os debates públicos na Década de 1950, sobre a escassez de alimentos que estavam intrinsecamente relacionados às questões e condições socioambientais, pois diziam respeito às formas ocupação e exploração dos recursos naturais pela agroindústria na Serra do Ororubá e regiões circunvizinhas, terras Xukuru tradicionalmente invadidas por fazendeiros muito deles membros da oligarquia política municipal. Com esse estudo, buscamos conhecer e melhor compreendermos as condições de vida indígena no citado período e a partir de outra abordagem, a História Ambiental, estabelecer as relações entre grupos humanos e a condições de vida no espaço onde habitam. Ou seja, contribuir para uma história socioambiental, elaborada a partir de um olhar que evidencie as relações de poder, privilegiando grupos socialmente excluídos nas interações com o Ambiente. 


\section{Referências bibliográficas}

ALMEIDA, Eliene A. de. Xucuru, filhos da mãe Natureza: uma história de resistência e luta. 2a ed. Olinda: CCLF/ Pesqueira Prefeitura Municipal, 2002.

ANDRADE, Manuel Correia de. A terra e o homem no Nordeste. $4^{\text {a }}$ ed. São Paulo: LECH, 1980.

CAVAlCANTI, Célia Maria de Lira. Acumulação de capital e a industrialização em Pesqueira (Pernambuco). Recife, Dissertação (Mestrado), Universidade Federal de Pernambuco, 1979.

CHACON. E. M.. "A carência de frutas e legumes". A voz de Pesqueira, 12/11/1950, p.1.

DRUMMOND, José Augusto. 1991. A história ambiental: temas, fontes e linhas de pesquisa. Estudos Históricos,4 (8):97-117.

FEITOSA, Raymundo Juliano Rego. Capitalismo e camponeses no Agreste pernambucano: relações entre indústria e agricultura na produção de tomate me Pesqueira/PE. Recife, Dissertação (Mestrado), Universidade Federal de Pernambuco, 1985.

GALVÃO, Sebastião de Vasconcellos. Diccionario chorographico, histórico e estatístico de Pernambuco. Rio de Janeiro, 1908.

HALBWACHS, Maurice. A memória coletiva. São Paulo: Centauro, 2004.

HONORATO, Manoel da Costa. Dicionário topográfico, estatístico e histórico de Pernambuco. $2^{\mathrm{a}}$ ed., Recife: Secretaria de Educação e Cultura, 1976.

MELO, Mário Lacerda de. Os agrestes. Recife: SUDENE,1980.

SILVA, Edson H. Xukuru: memórias e história dos índios da Serra do Ororubá (Pesqueira/PE), 1950-1988. Campinas, Tese (Doutorado), Universidade Estadual de Campinas 2008.

SETTE, Hilton. Pesqueira: aspectos de sua Geografia Urbana e de suas interrelações regionais. Tese Concurso Cadeira de Geografia do Brasil do Colégio Estadual de Pernambuco. Recife, 1956.

SOBRINHO, Vasconcelos. As regiões naturais do Nordeste, o meio e a civilização. Recife: Condepe, 2005.

TORRESa, Olímpio Pe. Serra do Ororubá. A voz de Pesqueira, 14 jun.1953, p.1.

TORRESb, O. Pe. Ainda a Serra. A voz de Pesqueira, 21 jun.1953, p.1.

TORRESc, O. Pe. Feira. A voz de Pesqueira, 28 jun.1953, p.1.

TORRESd, O. Pe. Medida acertada. A voz de Pesqueira, 05 jul.1953, p.1.

\section{Entrevistas}

ARAÚJO, Maria Alves Feitosa. "Dona Lica", 52 anos. Aldeia Cana Brava, Serra do Ororubá, Pesqueira/PE. Entrevista em15/12/05.

ARAÚJO, Zenilda Maria de. 55 anos. Aldeia Santana, Serra do Ororubá, Pesqueira/PE. Entrevista em 04/07/05. BISPO, Pedro Rodrigues. "Seu” Zequinha (Pajé Xukuru), 72 anos. Bairro Baixa Grande, Pesqueira/PE. Entrevista em 05/07/04.

CORDEIRO, Milton Rodrigues. 57 anos. Aldeia Gitó, Serra do Ororubá, Pesqueira/PE. Entrevista em18/12/05

PAZ, José Antônio Luiz da. "Seu” Dedé, 48 anos. Aldeia Santana, Serra do Ororubá, Pesqueira/PE. Entrevista em 08/04/2004.

RAMOS, Malaquias Figueira. 62 anos. Aldeia Caípe, Serra do Ororubá, Pesqueira/PE. Entrevista em 12/11/05. SANTOS, Laurinda Barbosa dos. "Dona Santa", 89 anos. Aldeia Caípe Serra do Ororubá, Pesqueira/PE. Entrevista em 12/11/05.

SOUZA, Cassiano Dias de. 75 anos. Aldeia Cana Brava, Serra do Ororubá, Pesqueira/PE. Entrevista em 13/12/05.

SILVA, Gercino Balbino da. 80 anos. Aldeia Pedra D’Água, Serra do Ororubá, Pesqueira/PE. Entrevista em $11 / 08 / 04$.

SILVA, Juvêncio Balbino da. 76 anos. Aldeia Cana Brava, Serra do Ororubá, Pesqueira/PE. Entrevista em $15 / 12 / 05$. 